\title{
Predatory exchange rate misalignments and the imbalance of the multilateral trade system: why this should be a WTO prerogative?
}

\author{
Desalinhamentos cambiais predatórios e o desequilíbrio do sistema \\ multilateral de comércio: por que isso deveria ser uma prerrogativa da OMC?
}

Lucas Baggi de Mendonça Lauria ${ }^{1}$

\begin{abstract}
RESUMO
A prática de desalinhamentos cambiais predatórios possui papel de significativa importância para o comércio internacional, uma vez que fere a lógica do multilateralismo. Dada a possibilidade de praticar tais desalinhamentos para sobrepujar decisões fruto de negociações no âmbito da OMC, quais os papéis do FMI e da OMC na abordagem desse problema? Por quais motivos essa seria uma prerrogativa da OMC? O objetivo principal desse artigo é fomentar o atual debate sobre a questão, apresentando os principais argumentos a favor de uma ação mais assertiva da OMC no tratamento dos desalinhamentos cambiais predatórios.
\end{abstract}

Palavras-chave: WTO; desalinhamentos cambiais predatórios; multilateralismo.

\begin{abstract}
The practice of exchange rate misalignments plays an important role on the international trading system, since it seriously undermines the rationale of multilateralism. Given the possibility of practicing exchange rate misalignments to overlap the achievements from WTO negotiations, what are the roles of the IMF and the WTO addressing this problem? Why this should be a WTO prerogative? The current article aims to foster the current debate, presenting the main motives why the WTO should play an important role regarding the predatory exchange rate misalignments.
\end{abstract}

Keywords: WTO; exchange rate misalignments; multilateralism;

\section{Introduction}

The General Agreement on Tariffs and Trade (GATT) was never designed to be a stand-alone agreement. Instead, it was meant to be part of a broader agreement conceived in the context of the Bretton Woods Conference, where the International Trade Organization, the International Monetary Fund and the World Bank were

\footnotetext{
${ }^{1}$ BA in International Relations, University of Brasília, UnB, Brasília, Brazil.
} 
supposed to work together in order to promote international development (SURANOVIC, 2012, p. 28). The GATT, and consequently the WTO, inherited from the almost created ITO the willingness of promoting trade liberalization by establishing rules that members should adopt. The IMF, in turn, was established to supervise exchange rate policies and safeguard the balances of payment of its parts. The World Bank, initially, would assist the post-war reconstruction and development. Today's Bank, however, has sharpened its focus on poverty reduction as the overarching goal of all its work.

Regarding the relation of financial issues and trade, a direct institutional dialogue was created through the IMF Article IV and GATT Article XV (THORSTENSEN et al., 2012, p. 1-3). This direct dialogue had a meaningful fashion importance, since there is no trading system immune to exchange rate misalignments (Ibid.). The issue made headlines in the trade economic context from the 1990s onwards, when sustained deviations of exchange rates were suspected to be at the origin of global account imbalances (AUBOIN and RUTA, 2011, p. 04). Definitely, the practice of exchange rate misalignments plays an important role on the international trading system, since it seriously undermines the rationale of multilateralism. In the first decade of the 2000's, the international system witnessed a considerable enlargement of trade relations, while the exchange rate misalignments were gradually increasing.

In this context, it should be expected that WTO and IMF would have appropriate ways to deal with the problem. However, according to Thorstensen et al., (2012):

(...) neither the IMF has ever agreed to use its Article IV power to declare a country as a currency manipulator, nor have WTO members brought a member to the DSB - Dispute Settlement Body - to challenge it as a frustrator of other members' benefits under the trade system.

Therefore, it is observed that, without an effective WTO mechanism to neutralize the exchange rate misalignments, the multilateral trading system is, clearly, doomed to failure.

\section{Exchange rate misalignments}

According to the IMF (2007, p. 4), the real exchange rate is "misaligned" when:

(...) it is out of line with its economic fundamentals for a sustained period of time. The magnitude of the misalignment is the difference between the observed real 
exchange rate (RER) and a (non observed) "equilibrium" RER. An "overvalued" RER indicates that the value of the current RER is above its equilibrium value, with an "undervalued" RER indicating the opposite.

Exchange rate misalignments can be predatory if they are the result of a long term significant devaluation, which is not intended to fix an economic imbalance. Hence, it could be concluded that the currency is being manipulated to generate more bookings and get unfair advantage over trading partners (CAMPOS, 2013, p. 15). In conformance with Gagnon (2012), this predatory practice is also observed when the government buys or sells foreign currency to manipulate its exchange rate away from the equilibrium value or, in the same way, to prevent the exchange rate from moving toward its equilibrium pattern.

Generalized misalignments, since temporarily employed to solve an economic imbalance, are not a serious problem. However, when they are influenced by the willingness of eliminating trade comparative advantages, they are considered predatory (CAMPOS, 2013, p. 16). This unfair practice can be identified according to the economic conjuncture of the practitioner. If the economic indicators are favorable in any country, arguably its currency, ceteris paribus, would tend to remain in balance, and not to considerable devalue (Ibid). In this case, it can be inferred that the devaluation is employed in order to create an artificial advantage related to the national exportations, thereby imposing a sort of non-tariff barrier to the importation process (Ibid).

It's also important to point out that the exchange rate manipulators are characterized by an array of peculiar aspects. Gagnon (2012, p.6) enumerates, at least, three characteristics:

I. Countries must have foreign exchange reserves that are greater than the value of six months of goods and services imports;

II. Countries must have an average current account balance (as a percent of GDP) that is greater than zero;

III. Countries must have increased their reserve stocks relative to their GDP over the past 10 years.

Bearing these characteristics in mind, it's possible to identify many cases, for instance, Brazil, China and United States. 


\section{Brazil, China and United States as empirical examples}

In order to exemplify the rationale of exchange rate misalignments, three cases were selected, being them Brazil, China and United States. According to Thorstensen et al. (2014), Brazil presents a historic of exchange rate misalignments. Analyzing the graphic bellow, it can be noted that this practice has a high degree of persistence in this economy, since periods of negative misalignments tend to be followed by others negative, and the same goes for positive values (Thorstensen et al,. 2014).

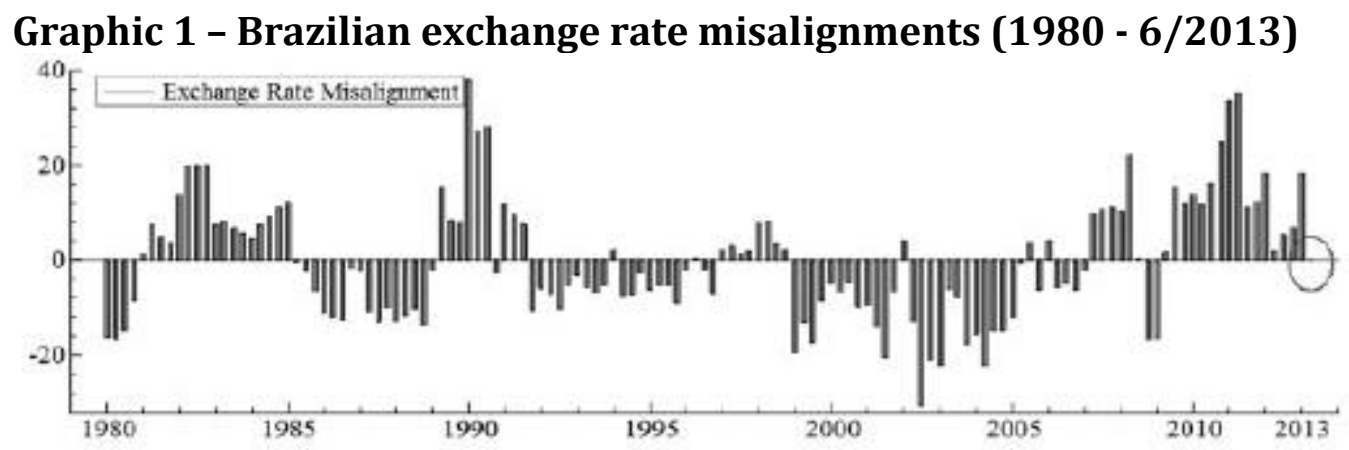

Source: Observatory on Exchange Rate (IMF, 2013) apud Thorstensen et al. (2014).

In line with Thorstensen et al. (2014), the United States' data of exchange rate misalignments suggests three moments of overvaluation of the dollar, as shown below:

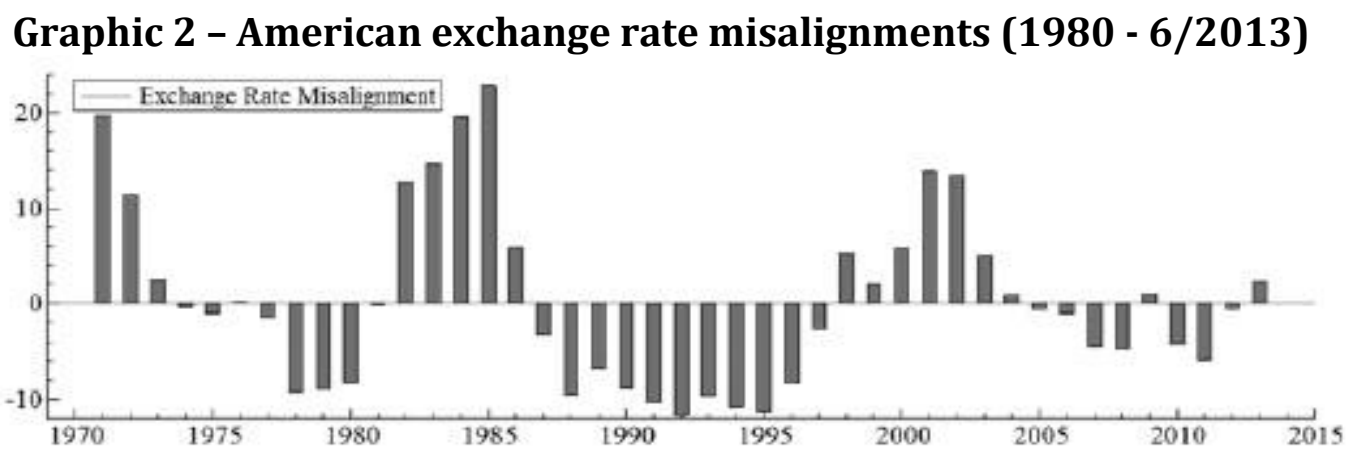

Source: Observatory on Exchange Rate (IMF, 2013) apud Thorstensen et al. (2014).

The inaugural period is placed in the first half of the 1970s. The second started in the mid-1980s, and the third, in turn, endured until the first half of the years 2000 . As reported by the Trading Economics (2015), it's also possible to note a further Conjuntura Global, vol. 4 n.3, set./dez., 2015, p. 382-389. 
considerable overvaluation, occurred in the end of 2015. The Chinese exchange rate, in turn, has been below its equilibrium since 2000. In 2011 and 2012 the estimated undervaluation was around $-15 \%$, as it can be observed by the graphic below:

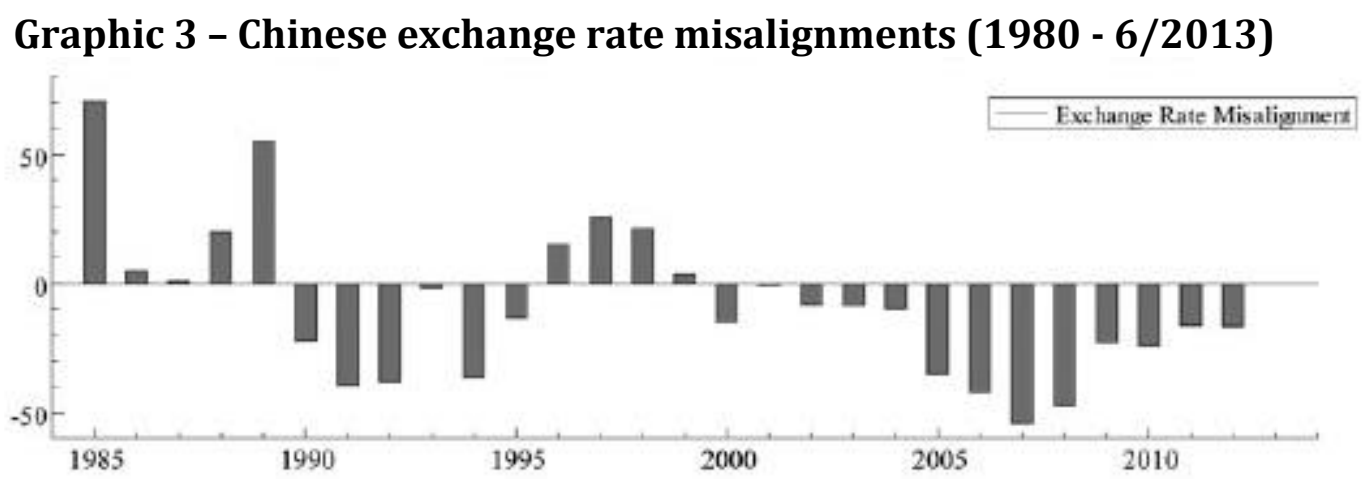

Source: Observatory on Exchange Rate (IMF, 2013) apud Thorstensen et al. (2014).

As stated by the International Valor (2015), in 2015, after a poor economic performance, China carried out the highest devaluation of the yuan in over 20 years. After have presented these three cases, there is one important question left: what is the impact of exchange rate misalignment to the international trading system?

\section{The impact of exchange rate misalignment}

Approaching the problem through a macroeconomic view, misalignments can have, at least, four impacts to the economy. They affect the structure of output and investment; they promote inefficient allocation of domestic absorption and external trade; they influence labor market and prices; and, lastly, they alter external accounts (WTO, 2011, p. 3). Regarding the international trading system, it has direct and indirect outcomes difficult to isolate and analyze (AUBOIN; RUTA, 2011, p. 04). According to Thorstensen et al. (2012, p. 13), they can affect the achievements from the WTO multilateral trade rounds. In this context, it's interesting to point out that, elements like the balance of tariffs or the market access concessions have been harmed by this sort of practice.

Countries adopting undervalued exchange rates, depending on its level, can have their bound and applied tariffs being increased than the notified tariffs. On the other hand, countries employing overvalued exchange rates would have them reduced or Conjuntura Global, vol. 4 n.3, set./dez., 2015, p. 382-389. 
nullified to negative levels. That said, each importing country will offer different market accesses to different exporter countries, which is a violation of GATT Article I. The overvalued countries, in turn, would be granting a stimulus to imports and also would be waiving the tariff protection level negotiated within the WTO (THORSTENSEN et al., 2012, p. 21).

\section{An institutionalist approach}

Given the possibility of practicing exchange rate misalignments to overlap the achievements from WTO negotiations, the responsible countries would be frustrating the provisions of the General Agreement on Tariffs and Trade - GATT (CAMPOS, 2013, pp. 17-18). According to the GATT article XV, paragraph 4:

Contracting parties shall not, by exchange action, frustrate* the intent of the provisions of this Agreement, nor, by trade action, the intent of the provisions of the Articles of Agreement of the International Monetary Fund (GATT, 1994, p. 25).

The word "frustrate" intends to indicate that the use of exchange misalignments to practice infringements, if there is an appreciable departure from the intent of the Article, shall be regarded as a violation (GATT, 1994, p. 67). The effects of exchange rate misalignment, in turn, should be considered clear examples of departure (CAMPOS, 2013, p. 18). When the frustration is clear, Campos (2013, p. 9) points out that seeking multilateral solutions would be the best alternative, since only by this path it would be possible to sustainably mitigate its negative effects. Yet, the solution is not obvious. It's common to imagine that the best one would be the requisition of a dispute settlement panel. However it can be noted that the WTO, even though having provisions regarding the frustrators, as the retaliation, does not act against them. In the current scenario, given the higher complexity of the issue and the technical controversial, the political pressures would be significant, once there is an array of differing interpretations regarding the WTO's prerogatives regarding the theme (CAMPOS, 2013, p. 19).

Analyzed the WTO's regulatory framework, it is interesting to note that the IMF, in turn, in its article of agreement number IV, recognizes the importance of the international monetary system, and also provides that each member shall: 
(...) avoid manipulating exchange rates or the international monetary system in order to prevent effective balance of payments adjustment or to gain an unfair competitive advantage over other members.

At the multilateral level, the IMF did not give evidences that will label any of its members to be manipulating its exchange rate (CAMPOS, 2013, p. 20). The articles of agreements also provide that the Fund shall exercise firm surveillance over the exchange rate policies of its members, and also shall adopt specific principles for the guidance of all with respect to those policies. At the same time, it disposes that the quoted principles shall respect the domestic social and political policies of them, being paramount to apply the principles according to the circumstances of its members (FMI, 2011, p. 07). It also can be noted that, even if the IMF acts against the exchange rate misalignments practitioners, it would sets up a procedure without deadlines, unstable at political pressures and without any sort of sanction to offer compensation for countries adversely affected by the negative impacts relating to trade (GAGNON, 2012, p. 1). Therefore, although currency manipulation to boost trade balances is a clear a violation of the Articles of Agreement of the International Monetary Fund (IMF), there is no currently procedure to punish or curtail it (Ibid).

\section{Is this a WTO prerogative?}

Undoubtedly it is. The best institutional approach for the exchange rate misalignments can be achieved through the WTO provisions, however, only if it operates in consultation with the IMF, as Gagnon (2012, p. 1) pointed out. The WTO, as quoted before, was never designed to be a stand-alone organization. Instead, it was meant to be part of a broader concertation, wherein the IMF plays a great role.

In this rate reality of exchange misalignments, a mechanism to neutralize exchange rate effects on tariffs and other trade instruments becomes necessary. Definitely this mechanism would be a permanent and sustainable solution, allowing the maintenance of the WTO previous achievements, such as the level of market access established, and the remedies imposed by investigations of unfair trade (THORSTENSEN et al., 2012, pp. 20-21). It's important to note that this new specific mechanism to address the issue shall come from a multilateral concertation under the WTO. However, without an appropriate incentive for the practitioners, such action will be impossible 
(CAMPOS, 2013, p. 15). In this context, a plurilateral action embedding the use of coordinated trade defense measures with the prominent WTO's surveillance should be the order. The WTO procedures in relation to the predatory misalignments, in contrast to the IMF, provide specific deadlines, relative short terms and, in special cases, trade retaliation against respondent countries (CAMPOS, 2013, p. 20). In order to get a manipulator to agree to the international trade legal framework, mainly based on the WTO provisions, countries harmed by the exchange rate predatory misalignments would be authorized to impose tariffs on imports from manipulators. Following this path, the predatory exchange rate misalignments would be gradually mitigated.

\section{References}

AUBOIN, M.; RUTA, M. The relation ship between exchange rates and international trade: a literature review. Word Trade Organization, Economic Reserch and Statistica Division, 27 Oct. 2011 (Staff Working Paper, ERSD-2011-17).

CAMPOS, Aluisio De Lima. "Boletim De Economia E Política Internacional."Boletim De Economia $\begin{array}{lllll}\text { E } & \text { Política } & \text { Internacional 15-20. }\end{array}$ Http://www.ipea.gov.br/portal/index.php?option=com content-\&view=article\&id=19876, Web. 15 Aug. 2015.

GAGNON, J. E. Combating widespread currency manipulation. PIIE: Policy Brief, July 2012.

IMF (2011). Articles of agreement. https://www.imf.org/external/pubs/ft/aa/Web. 15 Aug. 2015. THORSTENSEN, V.; MARÇAL, E.; FERRAZ, L. Exchange rate misalignments and trade policy: impacts on tariffs. Journal of world trade, v. 46, n. 3, p. 597-634, 2012.

Thorstensen, Vera, Marçal, Emerson, \& Ferraz, Lucas. (2014). Trade rules and exchange rate misalignments: in search for a WTO solution. Revista de Economia Política, 34(3), 370-395. http://www.scielo.br/scielo.php?script=sci arttext\&pid=S0101-31572014000300002\&lng=en\&tlng=en. 06 Jan. 2016.

Trading Economics (2015). United States Dollar 1967-2016. http://www.tradingeconomics.com/unitedstates/currency, Web. 06 Jan. 2016.

Valor Econômico (2015). Maior desvalorização do yuan em 20 anos sacode mercados pelo mundo. http://www.valor.com.br/financas/4174950/maior-desvalorizacao-do-yuan-em-20-anos-sacodemercados-pelo-mundo, Web. 06 Jan. 2016.

WTO (1994) General agreement on tariffs and trade. https://www.wto.org/english/docs e/legal e/gat-t47 e.pdf, Web. 10 Aug. 2015. 